\title{
PVsyst Yazılımı ile 30 kW Şebekeye Bağlı Fotovoltaik Sistemin Modellenmesi ve Simülasyonu
}

\author{
Eyüp Akcan ${ }^{1,2}$, Melih Kuncan ${ }^{3 *}$, Mehmet Recep Minaz ${ }^{4}$ \\ ${ }^{1}$ Siirt Üniversitesi, Mühendislik Fakültesi, Elektrik-Elektronik Mühendisliği, Siirt, Türkiye (ORCID: 0000-0002-4133-4344) \\ 2 Batman Mesleki ve Teknik Anadolu Lisesi, Batman, Türkiye (ORCID: 0000-0002-4133-4344) \\ ${ }^{3}$ Siirt Üniversitesi, Mühendislik Fakültesi, Elektrik-Elektronik Mühendisliği, Siirt, Türkiye (ORCID: 0000-0002-9749-0418) \\ ${ }^{4}$ Siirt Üniversitesi, Mühendislik Fakültesi, Elektrik-Elektronik Mühendisliği, Siirt, Türkiye (ORCID: 0000-0001-8046-6465)
}

(İlk Geliş Tarihi 20 Ocak 2020 ve Kabul Tarihi 23 Şubat 2020)

(DOI: $10.31590 /$ ejosat.685909)

ATIF/REFERENCE: Akcan, E., Kuncan, M., \& Minaz, M.R. (2020). Pvsyst Yazılımı ile 30 kW Şebekeye Bağlı Fotovoltaik Sistemin Modellenmesi ve Simülasyonu. Avrupa Bilim ve Teknoloji Dergisi, (18), 248-261.

$\ddot{O} z$

Elektrik enerjisi, son yüzyılda, insanlığın günlük yaşam standartlarında temel bir gereklilik haline gelmiştir. Dünyada elektrik enerjisi ihtiyacı her geçen gün artmaktadır. Bu yüksek elektrik enerjisi ihtiyacının tedarik edilmesinde şu anda ağırlıklı olarak termal veya hidroelektrik enerji üretim santrallerinden faydalanılmaktadır. Elektrik enerjisi üretiminin olumsuz etkileri olan sera gazı emisyonu ve diğer çevresel olumsuzluklarla ilgili artan endişe, elektrik üretimi için PV (fotovoltaik) sistemler gibi yenilenebilir enerji teknolojilerinin giderek daha fazla farkındalık, önem ve talep görmesine sebep olmaktadır.

Çevre dostu elektrik üretim sistemlerine olan talep, her geçen gün daha fazla artış göstermektedir. Bu artışa karşılık verebilmek için, yenilenebilir enerji tabanlı üretimde, güneş fotovoltaik tabanlı enerji üretim sistemlerinin en değerli katkı payına sahip olması dolayısıyla, küresel anlamda bu sistemlere büyük bir odak oluşmuş durumdadır. Elektrik enerjisi üretiminde güneş enerjisinden faydalanmak için genel olarak güneş fotovoltaik teknolojisi kullanılmaktadır. Bu açıdan bakıldığında güneş enerji potansiyeli yüksek olan Türkiye için, PV sistemler çok büyük önem taşımaktadır. PV enerji sistemlerinin performansına, coğrafi konumun ve güneş görme potansiyelinin yanı sıra güneş modülü tipleri de etki etmektedir.

Bu makalede; Türkiye'nin güneydoğusundaki Batman ilinde birbirine bağl1 $30 \mathrm{~kW}$ güneş fotovoltaik şebekenin tam bir modellemesi ve simülasyonu gösterilmiştir. Performans oranını ve sistemde meydana gelen farklı kayıpları analiz etmek için PVsyst yazılım programı kullanılmıştır.

\section{Modeling and Simulation of $30 \mathrm{~kW}$ Grid Connected Photovoltaic System with PVsyst Software}

\begin{abstract}
In the last century, electrical energy has become a basic requirement in humanity's daily living standards. Electricity demand in the world is increasing day by day. Thermal or hydroelectric power plants are currently used to supply this high electrical energy requirement. Increasing concern about greenhouse gas emissions and other environmental adversities, which is adverse effects of electrical energy production; This causes renewable energy technologies such as PV systems for electricity generation to be kept increasing and demanded.
\end{abstract}

\footnotetext{
${ }^{3}$ Sorumlu Yazar: Siirt Üniversitesi, Elektrik-Elektronik Mühendisliği, Siirt, Türkiye (ORCID: 0000-0002-9749-0418), melihkuncan@siirt.edu.tr
} 
The demand for environmentally friendly electricity generation systems are increasing day by day. In order to respond to this increase, since solar photovoltaic (PV) based energy generation systems have the most valuable contribution, there is a great focus on these systems globally in renewable energy-based production. Solar photovoltaic technology is used to make use of solar energy in electrical energy production. In this respect, for Turkey with high potential for solar energy, PV systems are of great importance. In addition to the geographical location and solar vision potential, solar module types also affect the performance of PV energy systems. In this article; a complete modeling and simulation of the $30 \mathrm{~kW}$ solar photovoltaic interconnected network in Batman in southeastern Turkey, is shown. PVsyst software program was used to analyze the performance rate and the different losses occurring in the system.

Keywords: Solar energy systems, PV system, Modeling and Simulation, Grid Connected Photovoltaic Systems, PVsyst.

\section{Giriş}

Elektrik enerjisi; tarım, sanayi, binalar, ulaşım gibi birçok uygulama alanlarında gereklidir. Enerji üretimi için kömür gibi fosil yakıtların tüketimindeki artış, küresel ısınmaya sebebiyet verip çevreyi olumsuz şekilde etkileyen yüksek sera gazı emisyonlarına neden olmaktadır. Bu nedenle, insanlığın yakın gelecekteki natürel konforunun daha fazla bozulmaması için fosil yakıtlara alternatif olarak güneş, rüzgâr, biyokütle gibi temiz enerji kaynaklarının kullanılmasına ihtiyaç vardır. Bu kaynaklar, doğası gereği sürekli olarak yenilendiği için yenilenebilir enerji olarak adlandırılmaktadır. Alternatif enerji kaynaklarının sınırsız ve temiz kaynaklar olmaları onların enerji üretmede kullanımlarında artışa yol açmıştır. Yenilenebilir güneş enerjisi de küresel enerji krizine en umut verici çözümlerden biridir. Ayrıca elektrik hatlarını kırsal ve uzak bölgelere ulaştırmanın ekonomik olmayışı, Güneş fotovoltaik (PV) sistemlerini elektrik üretimi için dünya çapında tutulur hale getirmiştir [1-4].

Güneş 1şınlarının elektrik enerjisine çevrilmesinde fotovoltaik (PV) paneller kullanılır. Elektrik enerjisinin elde edilmesinde PV panellerin kullanılması çevre kirliliğini azaltırken enerji verimliliğini arttırmaktadır [3-5].

Güneş enerjisi, Güneş'in iç çekirdeğinde gerçekleşen füzyon (hidrojenin helyuma dönüşmesi) sebebiyle oluşan 1şıma enerjisidir. Atmosfer dişında güneş enerjisinin şiddeti, yaklaşık $1370 \mathrm{~W} / \mathrm{m}^{2}$ büyüklüğündedir. Ancak yeryüzüne ulaşan 1şıma miktarı atmosferdeki kırılmadan dolayı 0-1100 W/m2 değerlerinde görülür. Dünya yüzeyine ulaşan bu 1şımanın oluşturduğu enerjinin küçük bir kısmı dahi, mevcut enerji tükemimizin çok daha fazlasıdır. Güneş enerjisinden faydalanmaya yönelik araştırma ve çalışmalar özellikle 1970'li yıllardan sonra artmıştır. Güneş enerjisi sistemleri teknolojik açıdan ilerleme kaydederken maliyet açısından ise düşüş göstermiştir. Aynı zamanda temiz ve yenilenebilir bir enerji kaynağı olduğunu insanlığa kanıtlamıştır[6].

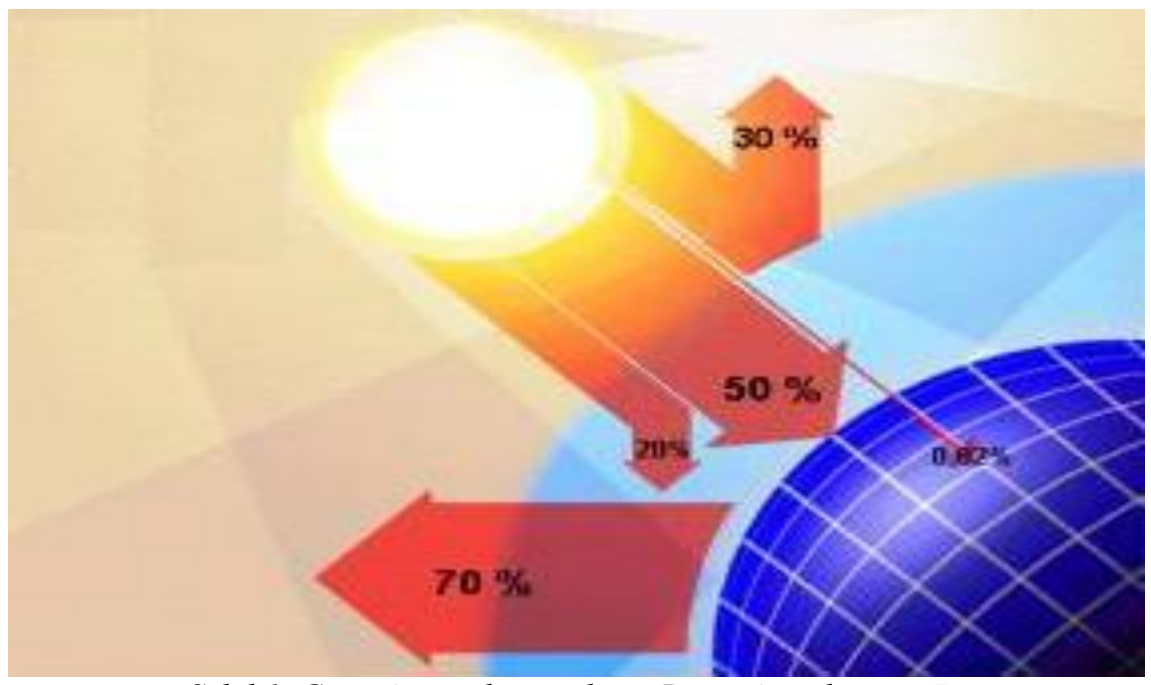

Şekil 1. Güneş’ten gelen ışınların Dünya'ya ulaşımı [7]

Şekil 1'de gösterildiği gibi; Güneş’ten gelen 1şımanın yaklaşık \%30'luk kısmı atmosferden geri yansır. Güneş 1şımasının yaklaşık \%50'si atmosferi geçip yeryüzüne ulaşır. Ulaşan bu 1şımanın enerjisi ile sıcaklık artar. Buna bağlı olarak yeryüzü yaşanılabilir hale gelir. Rüzgâr hareketlerine ve okyanuslardaki dalgalanmalara da bu ısınma sebep olur. Güneşten gelen 1şımanın yaklaşık \%20'lik kısmı ise atmosferde ve bulutlarda kalır. Yer yüzeyine gelen güneş 1şımasının \%1'den daha küçük kısmı ise bitkiler tarafından fotosentez yapılarak harcanır. Bitkiler, fotosentez sırasında güneş 1şığıyla birlikte karbondioksit ve su harcayarak, şeker ve oksijen üretirler. Fotosentez, yeryüzünde bitkisel yaşamın kaynağıdır. Güneş, nükleer enerji dışında kalan bütün enerjilerin dolaylı veya doğrudan kaynağıdır [6].

Fotovoltaik; kelime anlamı bakımından fotondan elektrik üretimi demektir. Bu üretim ise fotovoltaik paneller (PV) yardımı ile gerçekleştirilmektedir. Fotovoltaik sistemler, yaygın olarak Güneş’ten elektirik üretiminde kullanılmaktadırlar. Birçok bileşen bir araya gelerek fotovoltaik sistemleri oluşturur. Fotovoltaik sistemler sadece güneş panellerinden ibaret değildir. Panellerin yanı sıra akü, invertör ve şarj kontrol cihazı gibi bazı temel bileşenler de bu sistemler için oldukça önem taşımaktadır. Fotovoltaik sistemlerin en temel parçaları güneş ve elektriğin üretildiği kısımdır. Şarj kontrol cihazı; güneş panelinden gelen dc enerjiyi düzenleyip sabit tutar ve akülerin şarjı için stabil bir dc elektrik enerjisi oluşturur. İnverterler; DC elektrik enerjisini AC elektrik enerjisine dönüştüren cihazlardır. Akü kalitesi solar depolamalı off grid fotovoltaik sistemler için oldukça önemlidir [4, 8]. 


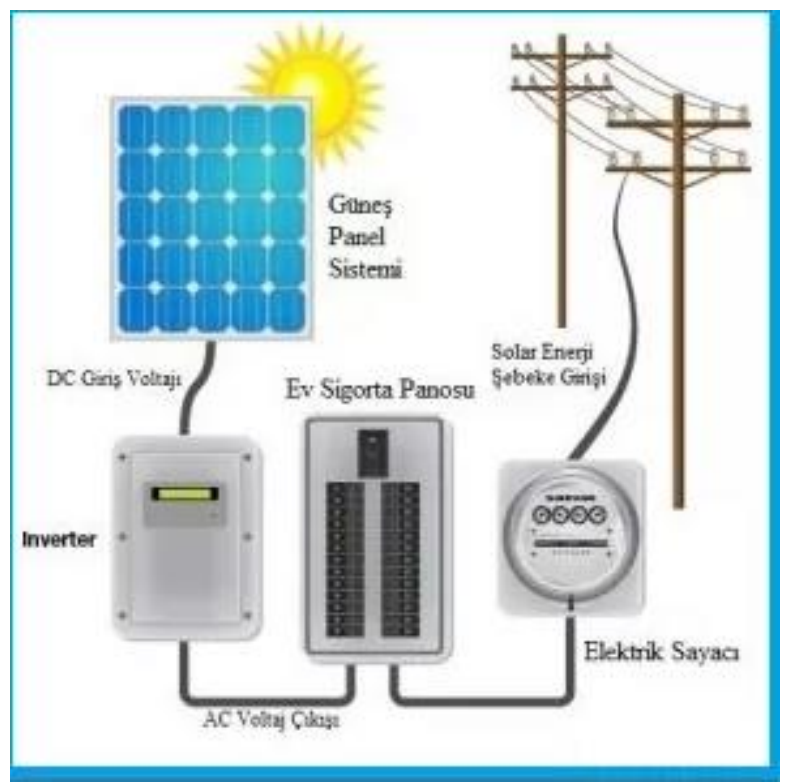

Şekil 2. Fotovoltaik Sistemler ile üretilen enerjinin On-Grid Sistem Şeması [8]

Bu çalışmada; PVsystV 6.8.5 yazılım programı kullanılarak, Batman merkezde bulunan bir okulun enerji ihtiyacının çatı tipi fotovoltaik sistemlerle karşılanması amacıyla tasarlanacak olan sistemin üreteceği enerji miktarı, sistem performansı ve sistemde bulunan elemanların birbirleriyle uyumluluğu üzerine değerlendirmeler yapılabilen simülasyon yapılması amaçlanmıştır. Binanın coğrafi konumu PVsyst yazılım programında belirtilmiş ve program içerisinde sunulan hizmetlerden biri olan Meteonorm 7.2 veri tabanından bölgenin meteoroloji verileri sentetik olarak üretilmiştir.

Şekil 2'de On-Grid șeması görülmektedir. Gün ıșığının olmadığı durumlarda okulun enerji ihtiyacının șebekeden karşılanacağı, yeterli olması durumunda ise üretim fazlasının şebekeye aktarılacağı şekilde tasarlanmıştır. Sistem performans analizi, IEC 61724 standartlarında belirtilen performans parametreleri dikkate alınarak yapılmıştır.

\section{Türkiye’nin Güneş Enerjisi Potansiyeli}

Coğrafi olarak, $36^{\circ}$ ile $42^{\circ}$ kuzey enlemleri ve $26^{\circ}$ ile $45^{\circ}$ doğu boylamları arasında bulunan Türkiye, güneş kuşağı içindedir. Türkiye Güneş Enerjisi Potansiyeli Atlasına (GEPA) göre, toplam güneşlenme süresi ylllık 2.741 saat (günlük ortalama 7,5 saat), gelen toplam güneş enerjisi $1.527 \mathrm{kWh} / \mathrm{m}^{2}$.yıl (günlük ortalama $4,18 \mathrm{kWh} / \mathrm{m}^{2}$.gün) olduğu hesaplanmıştır. Günlük ortalama

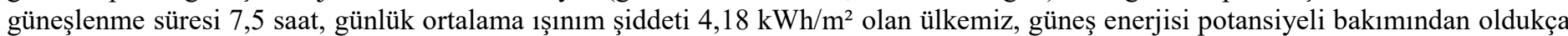
zengin bir ülkedir. Şekil 3.3'te, Türkiye'de illere düşen yıllık ışınım miktarlarını gösteren güneş enerjisi potansiyel atlası verilmiştir [9].
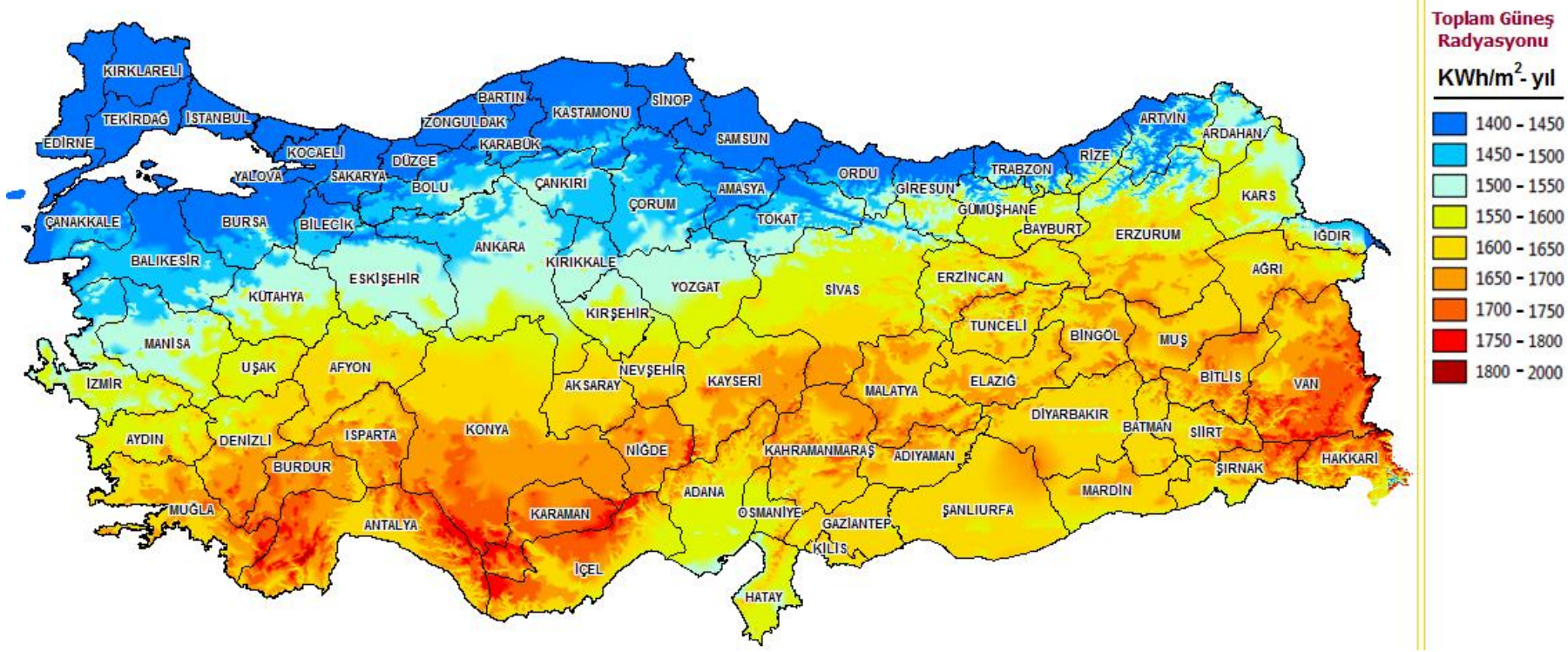

Şekil 3. Türkiye Güneş Enerjisi Potansiyeli Haritası(GEPA) [10] 
IULRIYE Gliball Radyasyom Degerleri (KWWh/m2-gin).

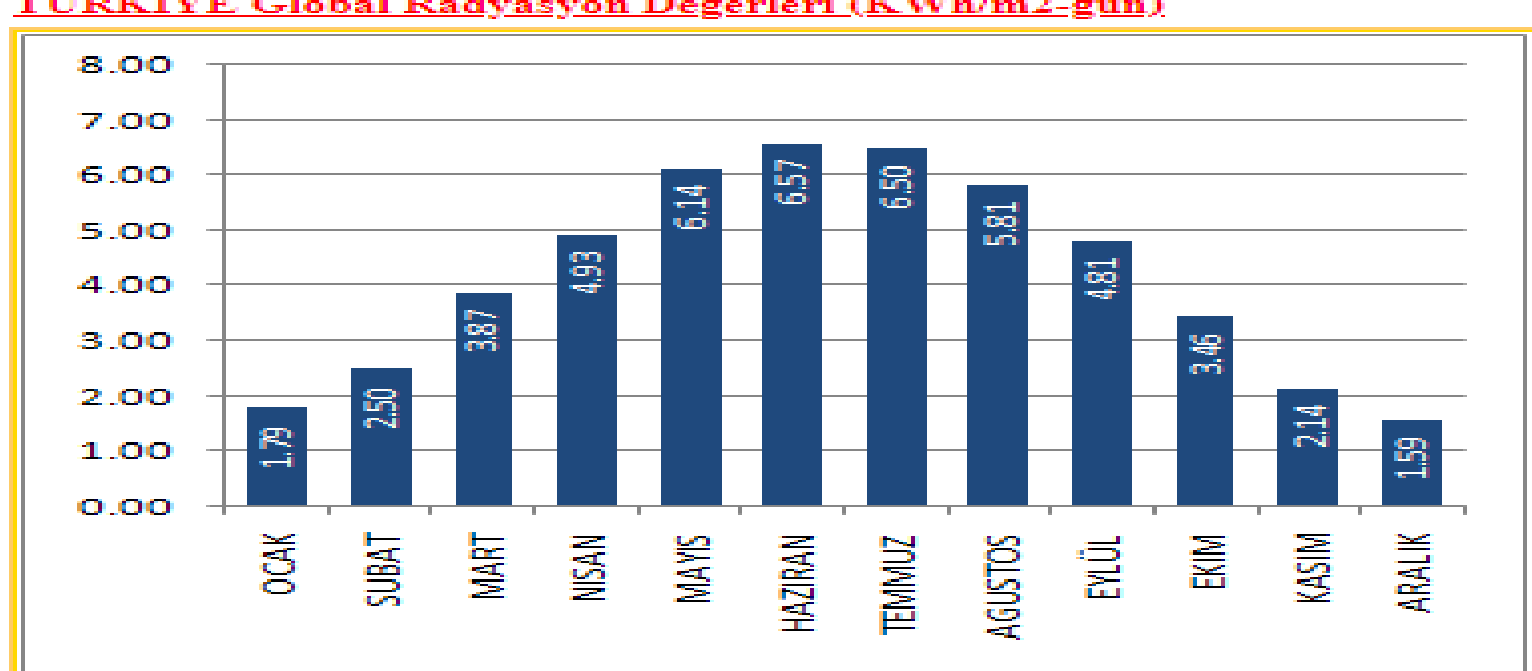

Şekil 4. Türkiye Global Radyasyon Değgerleri[10]

IÜRKIYE Güneslenme Süreleri (Saat).

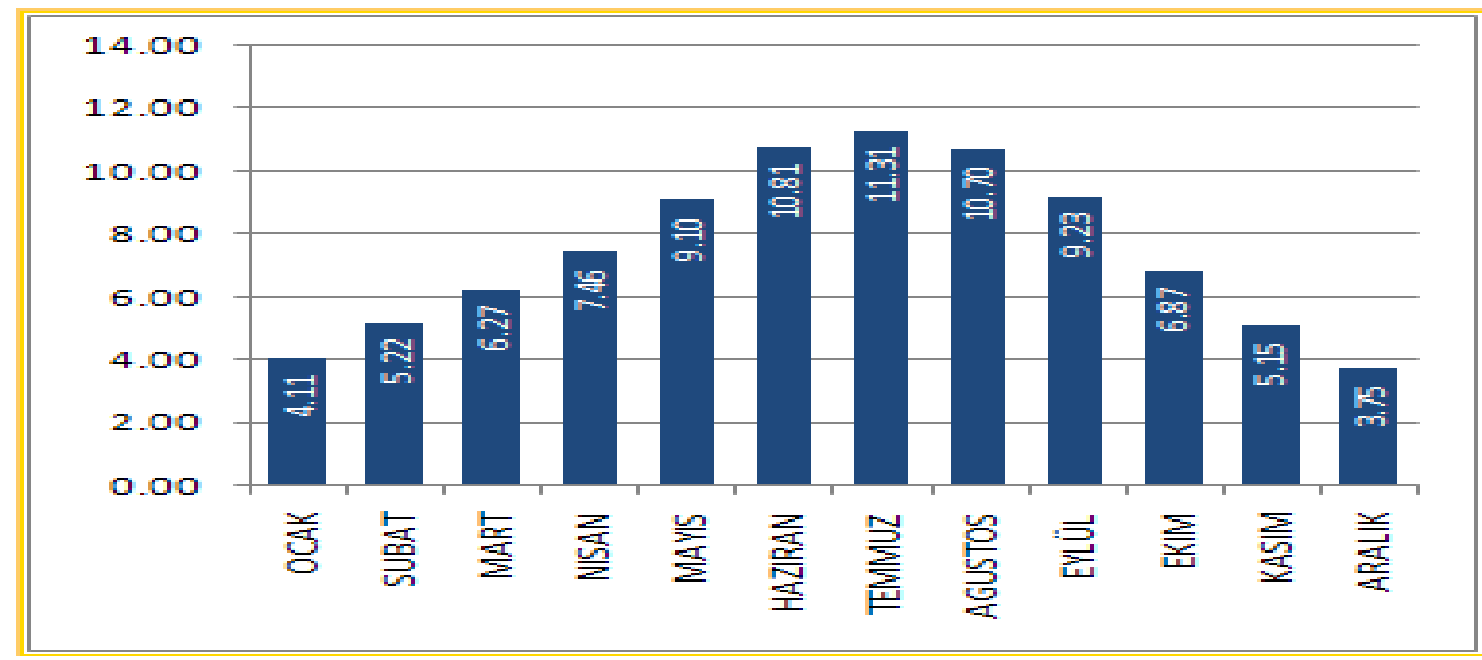

Şekil 5. Türkiye Güneşlenme Süresi(Saat) [10]

\section{TÜRKIYY PV Tipi-Alan-Üretilebilecek Enerji (KWh-Yıl).}

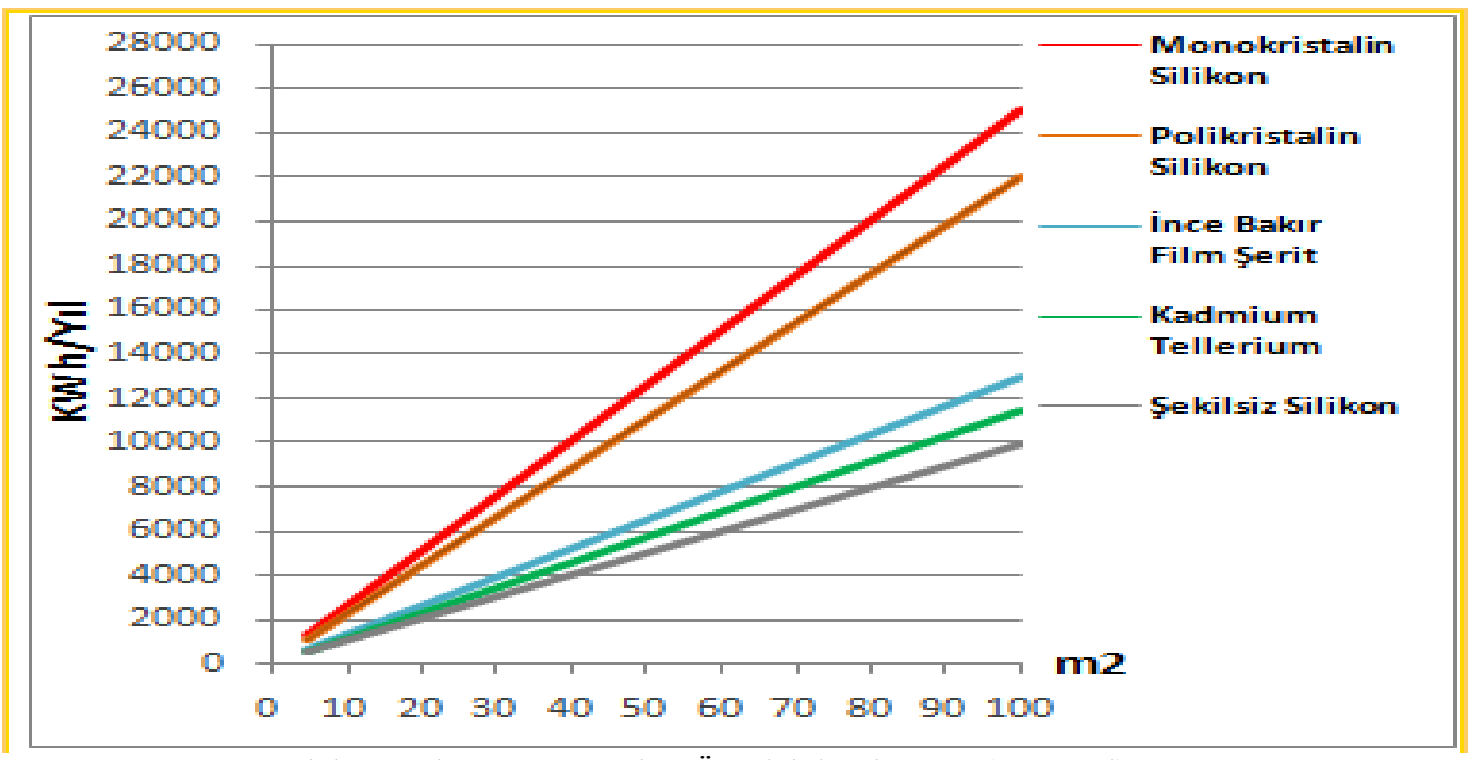

Şekil 6. Türkiye PV Tipi-Alan-Üretilebilecek Enerji(KwH-Yll) [10] 


\section{Batman'da Güneş Enerjisi Potansiyeli}
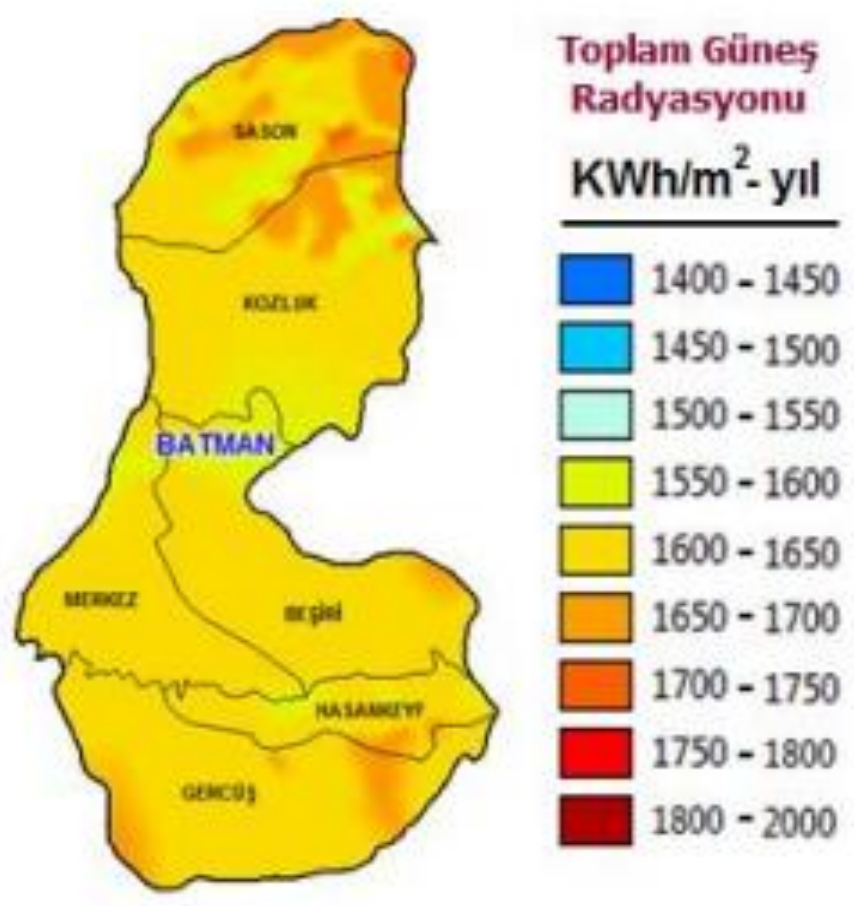

Şekil 7.Batman Güneş Enerjisi Potansiyel Atlası [11]

Karasal iklimin hakim olduğu Batman şehrinin kuzeyi ve kuzeydoğusunda sarp ve dağlık araziler, güneyinde ise engebeli araziler görülmektedir. Yaz ayları sıcak ve kurak geçen bu bölgede, kışlar soğuk ve yağışlıdır. Konum olarak Batman, 41 derece 10 dakika ve 41 derece 40 dakika doğu boylamları arasında; 38 derece 40 dakika 37 derece 50 dakika kuzey enlemleri arasında bulunmaktadır. Batman ilinin rakımı ise 550 metredir [12].

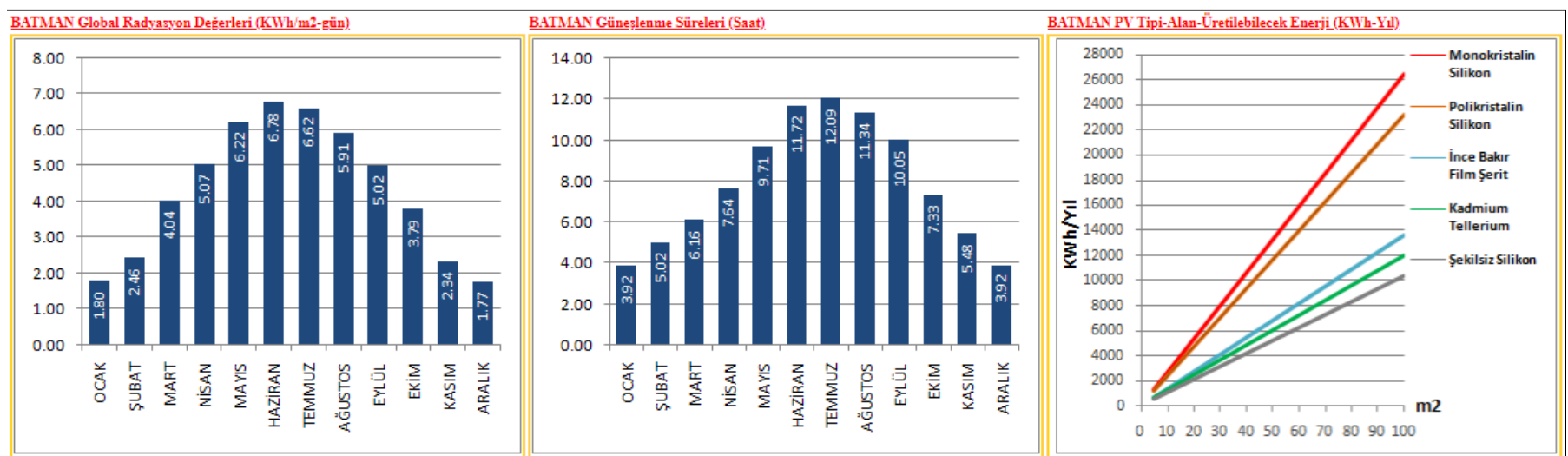

Şekil 8. Batman global radyasyon değeri, güneşlenme süresi, PV tipi[11]

\section{PVsyst Simülasyon Programı}

PVsyst programı, İsviçre Cenevre Üniversitesi tarafından geliştirilen, şebeke bağlantılı veya şebekeden bağımsız PV sistemler, PV sulama sistemleri ve DC şebekeler gibi fotovoltaik sistem tasarımlarının yapılıp sonuçlarının incelenmesi amacıyla kullanılan simülasyon programıdır. Bu program; benzerlerine kıyasla, daha detaylı hesaplamalara ve farklı parametrelerin kullanılmasına olanak sağlamaktadır [13].

Bir PV sistemi; bir PV dizisi, akü ve güç koşullandırma elemanları içerir. PV sistemi, güneş enerjisini DC enerjiye dönüştürür ancak kullanılan yükler çoğunlukla AC yüklerdir. Bu nedenle sistemde bulunan inverter, DC'yi AC'ye dönüştürür. PV sistem iki şekilde çalışabilir; şebekeye bağlı ve şebekeden bağımsız... Şebekeye bağlı PV sistemin elektrik enerjisi doğrudan şebekeyi besler ve geleneksel enerji kaynağına paralel çalışır. Şebekeye bağlı PV sistemi, iletim ve dağıtım kayıplarının olmaması veya pillere ihtiyaç 
duyulmaması için, elektriğin son kullanıcısına yakın bir yere kurulur. Performansı; yerel hava koşullarına, PV dizisinin yönüne, PV dizisinin eğimine ve inverter performansına bağlıdır [14].

\section{Fotovoltaik Sistem Tasarımı}

Şebeke bağlantılı ve enerji depolamalı bir PV (Photovoltaics-Fotovoltaik) sistemin, PVsyst programı ile gerçekleştirilmesi aşağıda kısaca anlatılmıştır.

\section{Coğrafi Konuma Ait Verilerin PVsyst Programına Girişi}

Coğrafi konuma ait verilerin girişi aşağıdaki sırayla girilerek yapılmaktadır.

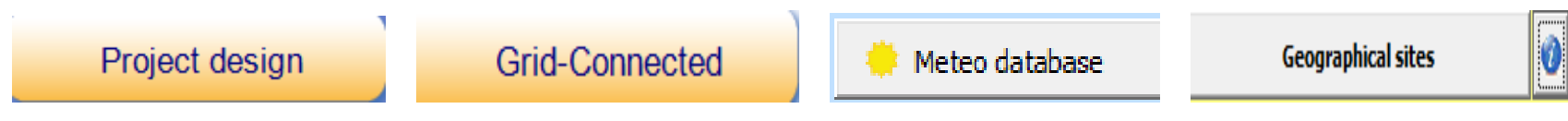

\begin{tabular}{|llll|}
\begin{tabular}{|l} 
Barkarby \\
Bastia/Poretta \\
Batamaj
\end{tabular} & $\begin{array}{l}\text { Barkarby } \\
\text { Bastia/Poretta } \\
\text { Batamaj }\end{array}$ & $\begin{array}{l}\text { Sweden } \\
\text { France } \\
\text { Russian Federation }\end{array}$ & $\begin{array}{l}\text { MeteoNorm 7.2 station } \\
\text { MeteoNorm 7.2 station } \\
\text { MeteoNorm 7.2 station }\end{array}$ \\
\hline Batman MN72.ST & Batman & Turkev & NASA-SSE satellite data 1983-2005 \\
\hline $\begin{array}{l}\text { Batman Nasa 1983.ST } \\
\text { Batsfiord }\end{array}$ & Batman & Turkey & MeteoNorm 7.2 station \\
Belfast/Alderqrove & Batsfiord & Norway & MeteoNorm 7.2 station \\
Belmullet Peninsula & Belfast/Alderarove & United Kingdom & MeteoNorm 7.2 station \\
Belmullet Peninsula & Ireland &
\end{tabular}

İstenilen coğrafi konuma çift tıklanır.

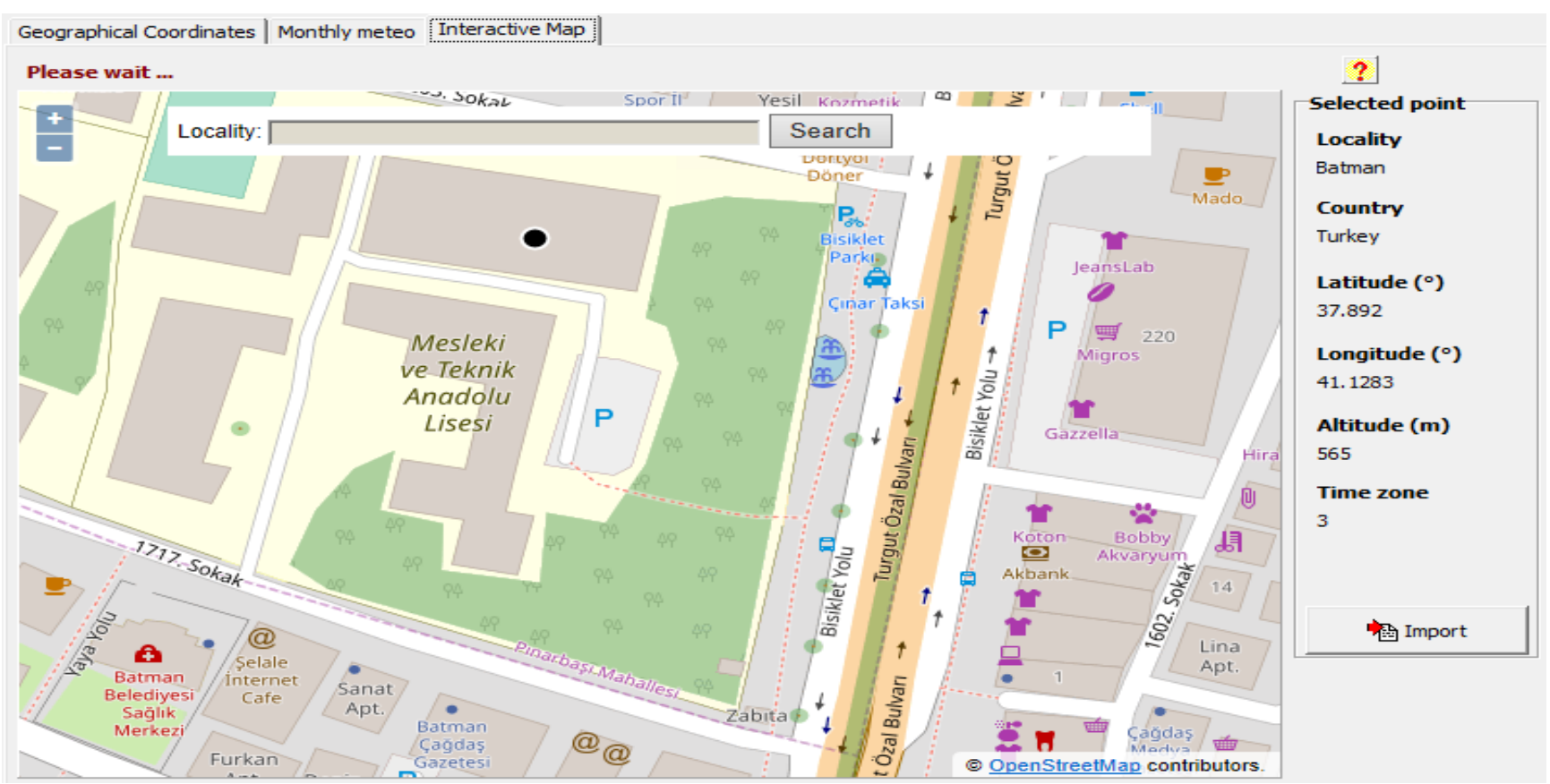

Şekil 9. Coğrafi koordinatlar giriş penceresi

İstenilen konum, Şekil 9'daki gibi belirlendikten sonra Import'a basılarak coğrafi konum bilgisi girilmiş olur. 


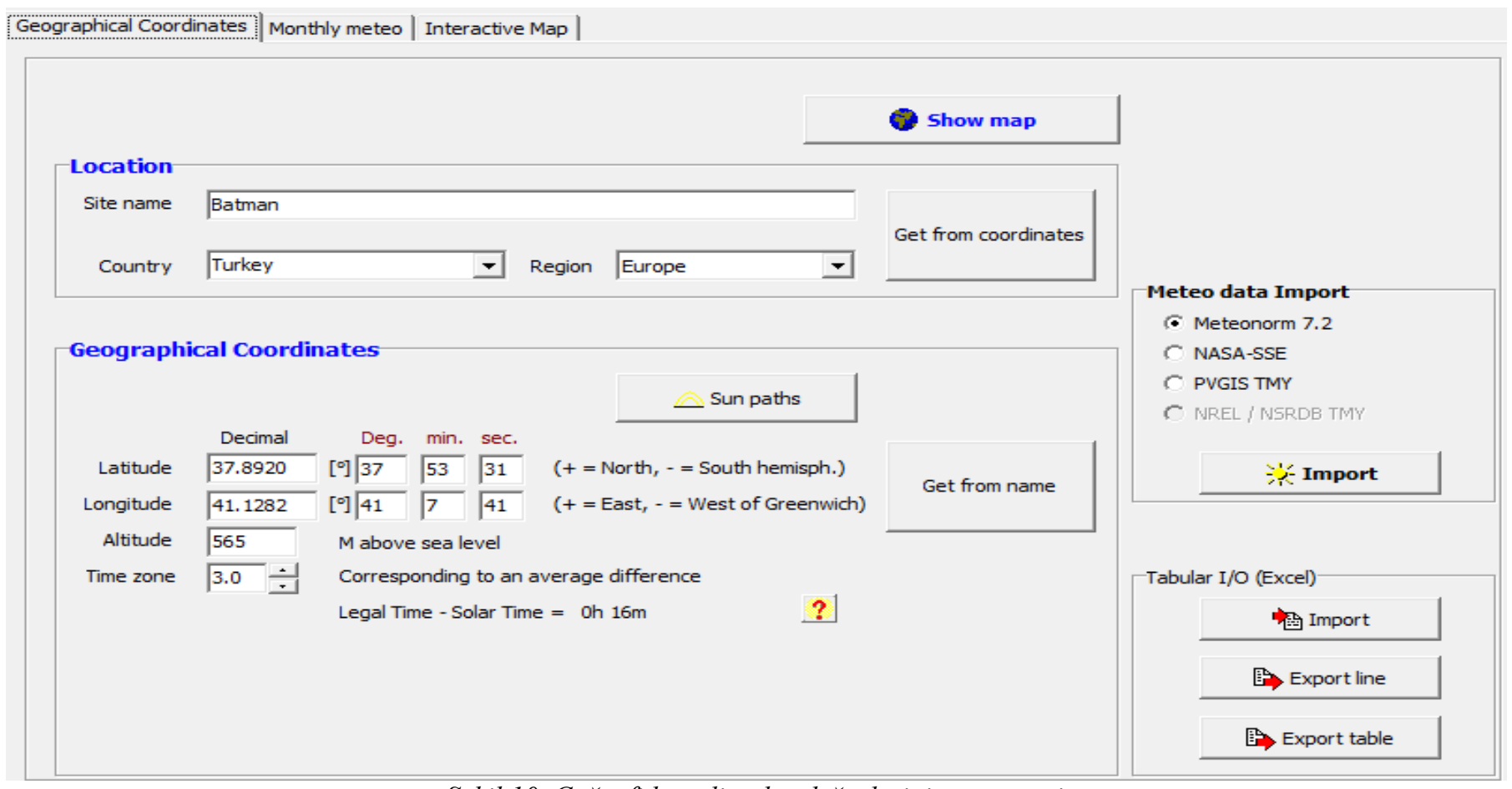

Şekil 10. Coğrafi koordinatlar değerlerinin penceresi

\section{Güneş PV Şebeke Sisteminin Tanımı}

Şebekeye bağlı bir PV sistemi; güneş panelleri, inverterler, bir güç koşullandırma ünitesi ve şebeke bağlantı ekipmanından meydana gelmektedir. Enerji depolama için kayıplar meydana gelmeyeceğinden dolayı güneş enerjisinden üretilen gücün etkin bir şekilde kullanılmasını sağlar. Önerilen model Şekil 11'de PV sistem yazılımı ile gösterilmiştir [15].

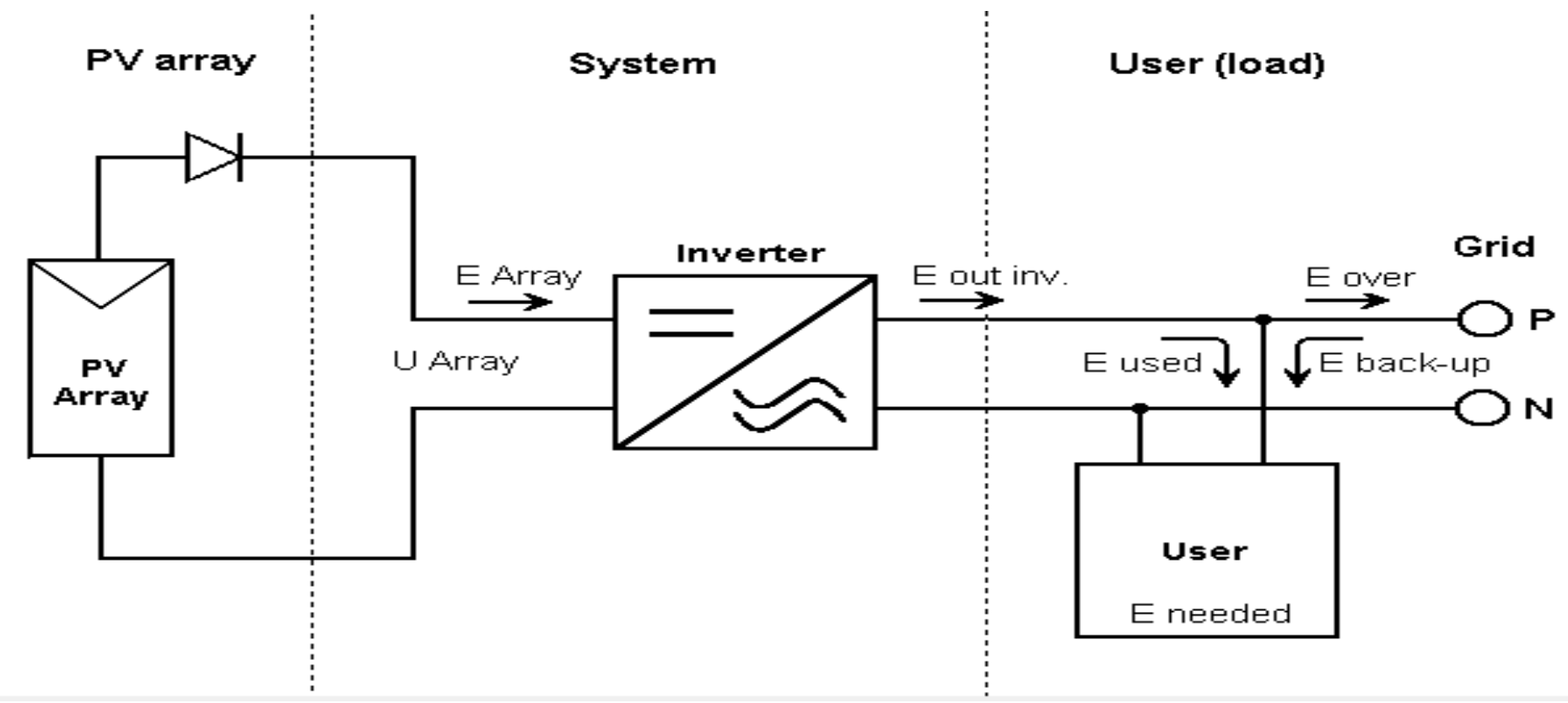

Şekil 11. Şebekeye bağll PV sistemi

\section{PV (Fotovoltaik) Sistemin Yönlendirmesi}

Orientation

Butonuna basılarak PV sistemin yönlendirilmesi yapılır. Batman iline ait coğrafi konum girilir ve azimut değeri sıfır oluncaya kadar enlem değeri değiştirilir. 
Güneş azimut açısı, herhangi bir bölgede ve zamanda, Güneş’e doğru varsayılan doğrunun, yataydaki izdüşümünün güney doğrultusu ile arasında kalan açıdır [16].

\section{Field type Fixed Tilted Plane}

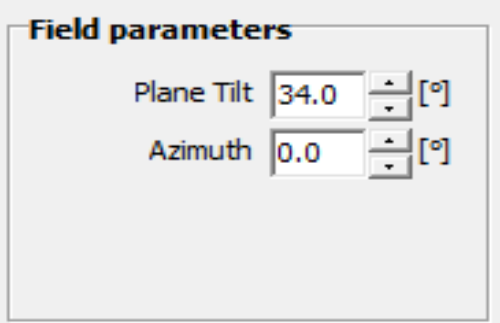

Tilt $34^{\circ}$

Optimization by respect to

( Yearly irradiation yield ?

C Summer (Apr-Sep)

(C) Winter (Oct-Mar)

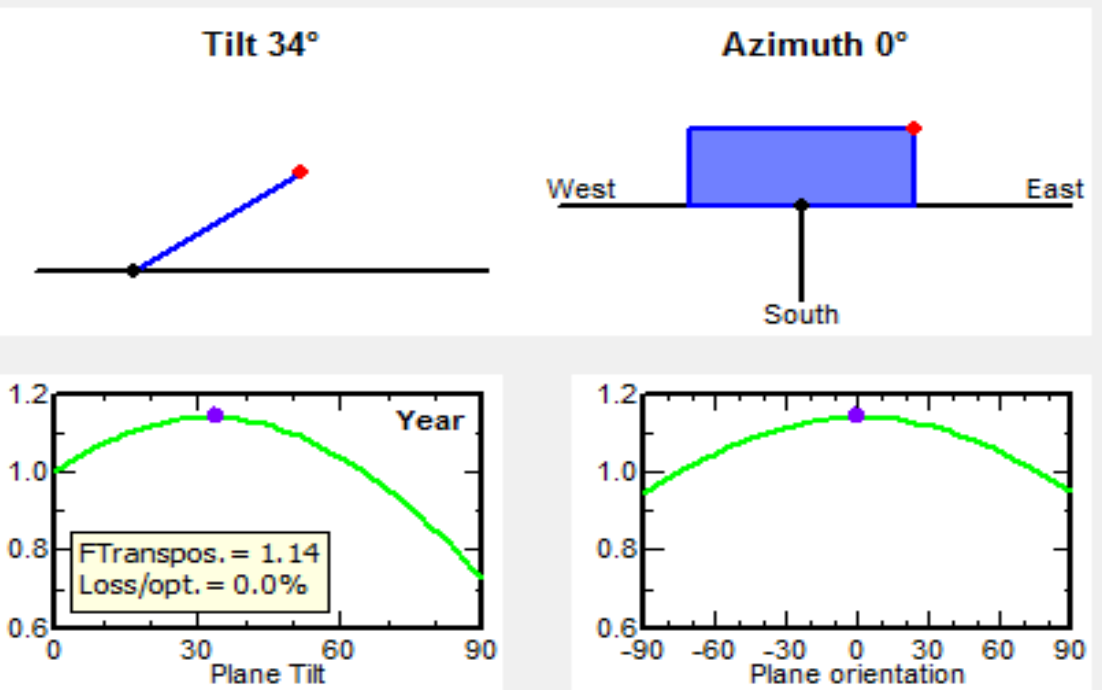

Şekil 12. PV Paneller için panel açısı ve Azimuth değer tablosu

\section{8. İnverter (Evirici) ve PV Panellerin Belirlenmesi}

\section{İnverter}

Fotovoltaik paneller kullanılarak enerji elde edilmesi aşamasında evirici, alternatif enerjinin anlık olarak incelenmesi ve depolama işlemleri hassas bir şekilde yapılmalıdır. Şebekeye bağlı herhangi bir sistemde, doğru akımı alternatif akıma dönüştürmek için inverter gereklidir. Inverter, tasarım için PVsyst yazılımında çok önemli bir rol oynamaktadır [17-19].

\begin{tabular}{|c|c|c|c|c|c|c|c|c|}
\hline \multicolumn{2}{|c|}{ Select the inverter } & \multirow{2}{*}{\multicolumn{6}{|c|}{ Output voltage $400 \mathrm{~V} \mathrm{Tri} 50 \mathrm{~Hz}$}} & \multirow{3}{*}{$\begin{array}{l}\sqrt{\nabla} 50 \mathrm{~Hz} \\
\nabla 60 \mathrm{~Hz} \\
\sqrt{8} \text { Open }\end{array}$} \\
\hline Available Now & $\nabla$ & & & & & & & \\
\hline Afore & $\nabla$ & $15 \mathrm{~kW}$ & $420-800 \mathrm{~V} \mathrm{TL}$ & $50 \mathrm{~Hz}$ & Anybuild BNT015KTL & Since 2012 & $\square$ & \\
\hline $\mathrm{Nb}$, of inverters & 1 & $\doteq \nabla$ & $\begin{array}{l}\text { Operating Vo } \\
\text { Input maximu }\end{array}$ & $\begin{array}{l}\text { age: } \\
\text { n voltage: }\end{array}$ & $\begin{array}{r}420-800 \mathrm{~V} \\
850 \mathrm{~V}\end{array}$ & $\begin{array}{l}\text { Global Inverter's power } 15.0 \mathrm{kWac} \\
\text { "String" inverter with } 6 \text { inputs }\end{array}$ & & \\
\hline
\end{tabular}

Şekil 13. Inverter Seçim Ekranı

Seçilen inverterin verimlilik eğrisi Şekil 14’te gösterilmiştir. 


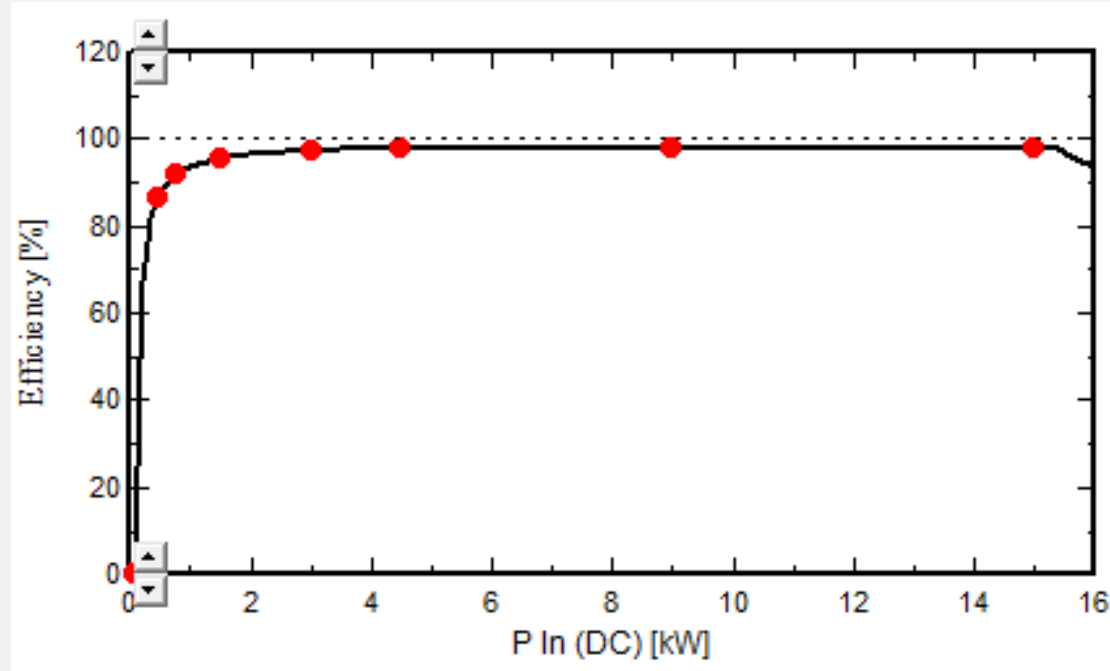

Şekil 14. İnverter Verimlilik Ĕgrisi

\section{Sistemde Kullanılacak PV Modülünün Belirlenmesi}

PVsyst programında, sistem tasarlanırken planlanan güç veya pv modüllerin yerleştirileceği mevcut alan üzerinden hesaplama yapılabilir. Bu çalışmada, $30 \mathrm{~kW}$ olarak planlanmış kurulu güç değeri esas alınarak PV panel ve inverter seçimi yapılmıştır.

System

\begin{tabular}{|c|c|c|c|c|c|c|c|c|c|c|}
\hline \multirow{2}{*}{$\begin{array}{l}\text { Available Now } \\
\text { Silfab }\end{array}$} & \multirow{2}{*}{$\begin{array}{l}\nabla \\
\nabla\end{array}$} & Filter & \multicolumn{2}{|c|}{ All PV modules } & $\nabla$ & & & Approx. needed modules & 50 & \multirow[b]{2}{*}{ 圈 Open } \\
\hline & & $300 \mathrm{~V}$ & VD $31 \mathrm{~V}$ & Si-poly & SLG $300 P$ & & Since 2014 & PV Evolution Lab & $\operatorname{os} 2 \div$ & \\
\hline - Use Optimizer & & & Sizin & voltages: & $\begin{array}{l}\operatorname{Vmpp}\left(60^{\circ} \mathrm{C}\right) \\
\operatorname{Voc}\left(-10^{\circ} \mathrm{C}\right)\end{array}$ & $\begin{array}{l}31.5 \mathrm{~V} \\
50.3 \mathrm{~V}\end{array}$ & & & & \\
\hline
\end{tabular}

Seçilen panele ait özellikler Şekil 16'da verilmiştir.

Şekil 15. PV Modül Seçim Ekranı

\begin{tabular}{|c|c|c|c|c|c|}
\hline Module & & & Cells & & \\
\hline Length & 1970 & $\mathrm{~mm}$ & In series & 72 & \\
\hline Width & 990 & $\mathrm{~mm}$ & In parallel & 1 & \\
\hline Thickness & 38.0 & $\mathrm{~mm}$ & Cell area & 243.4 & $\mathrm{~cm}^{2}$ \\
\hline Weight & $\longdiv { 2 3 . 0 0 }$ & $\mathrm{kg}$ & Total nb. cells & 72 & \\
\hline Module area & 1.950 & $\mathrm{~m}^{2}$ & Cells area & 1.752 & $\mathrm{~m}^{2}$ \\
\hline
\end{tabular}

Şekil 16. Panel özellikleri

Şekil 17'de 300 Watt'lık bir yük için Silfab SLG 300P PV karakteristik eğrisini göstermektedir. 
PV module: Silfab, SLG 300P

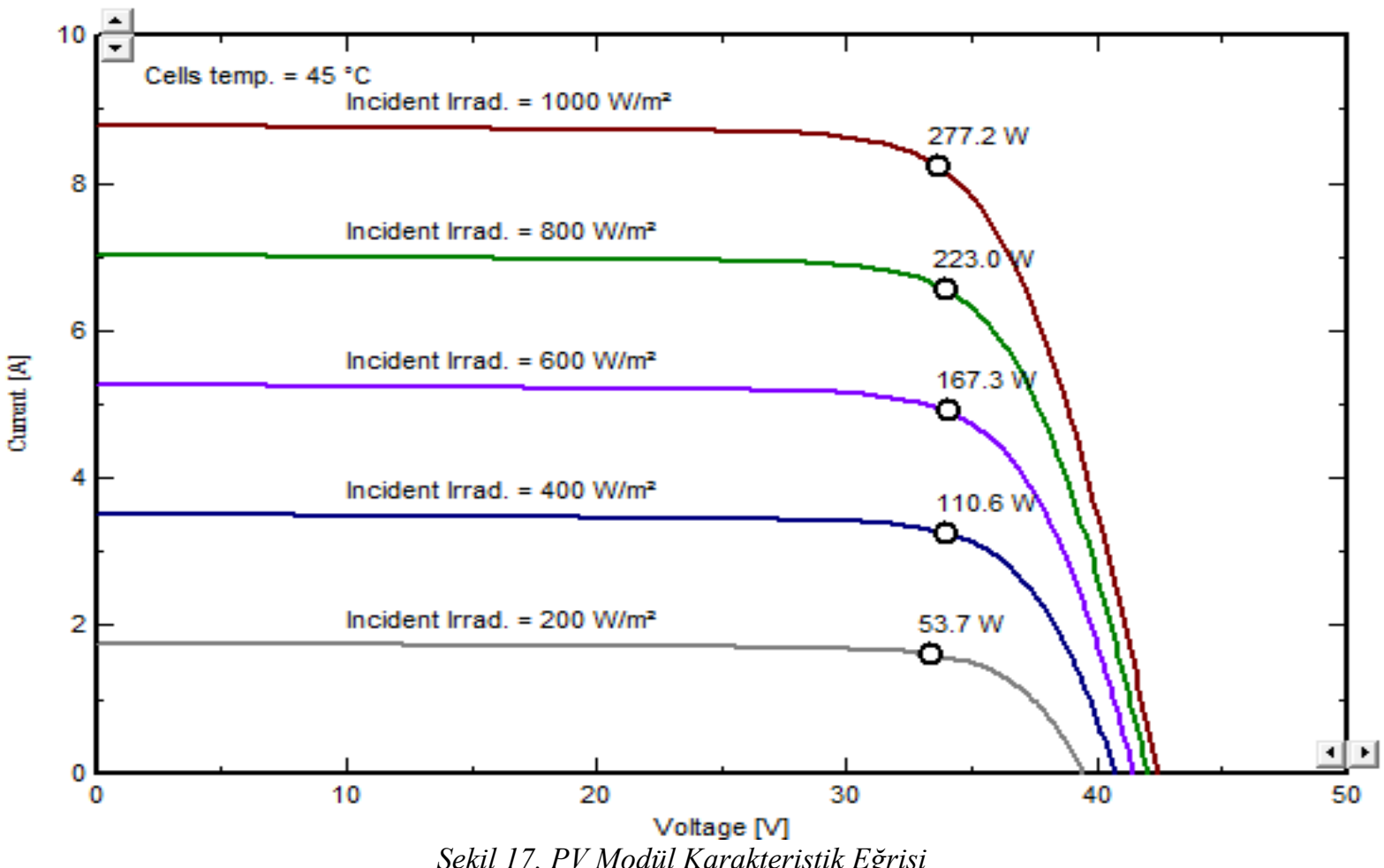

\section{PV Panel İçin Eğim ve Yönelim}

PV paneller, Batman ili için maksimum güneş 1şınımı elde etmek için Şekil 18'deki güneş yoluna göre en iyi yönlendirme için optimize edilmiş ve Şekil $12^{\prime}$ de gösterildiği gibi eğim açısının $34^{\circ}$ ve Azimut açısının $0^{\circ}$ olması gerektiği sonucu elde edilmiştir.

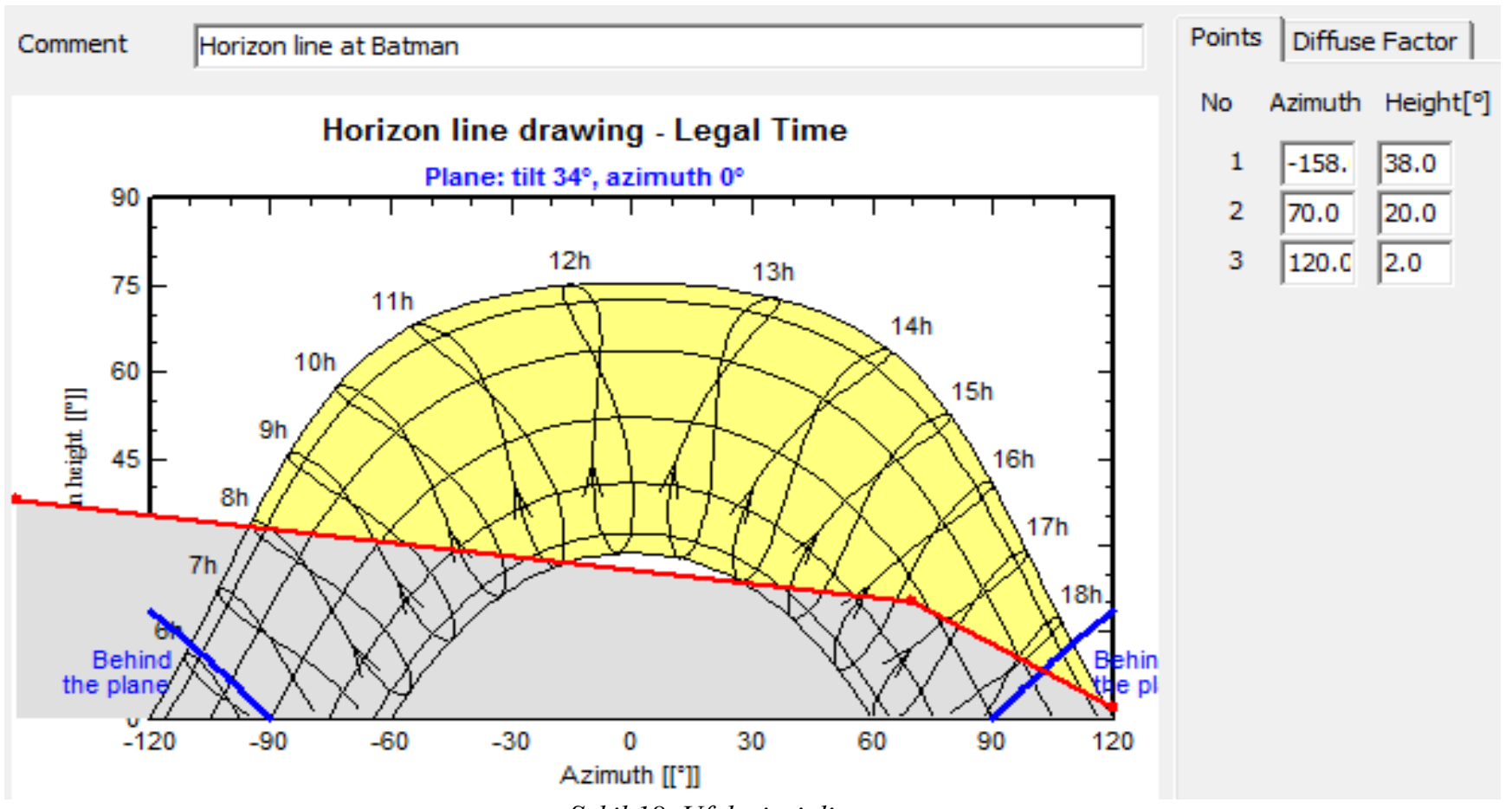

\section{PVSyst Simülasyon Sonuçları}

Şekil 19'da yılın her ayı için, olay enerjisinin performans oranının grafiksel bir temsilidir. Ortalama oran 0.668'dur. 


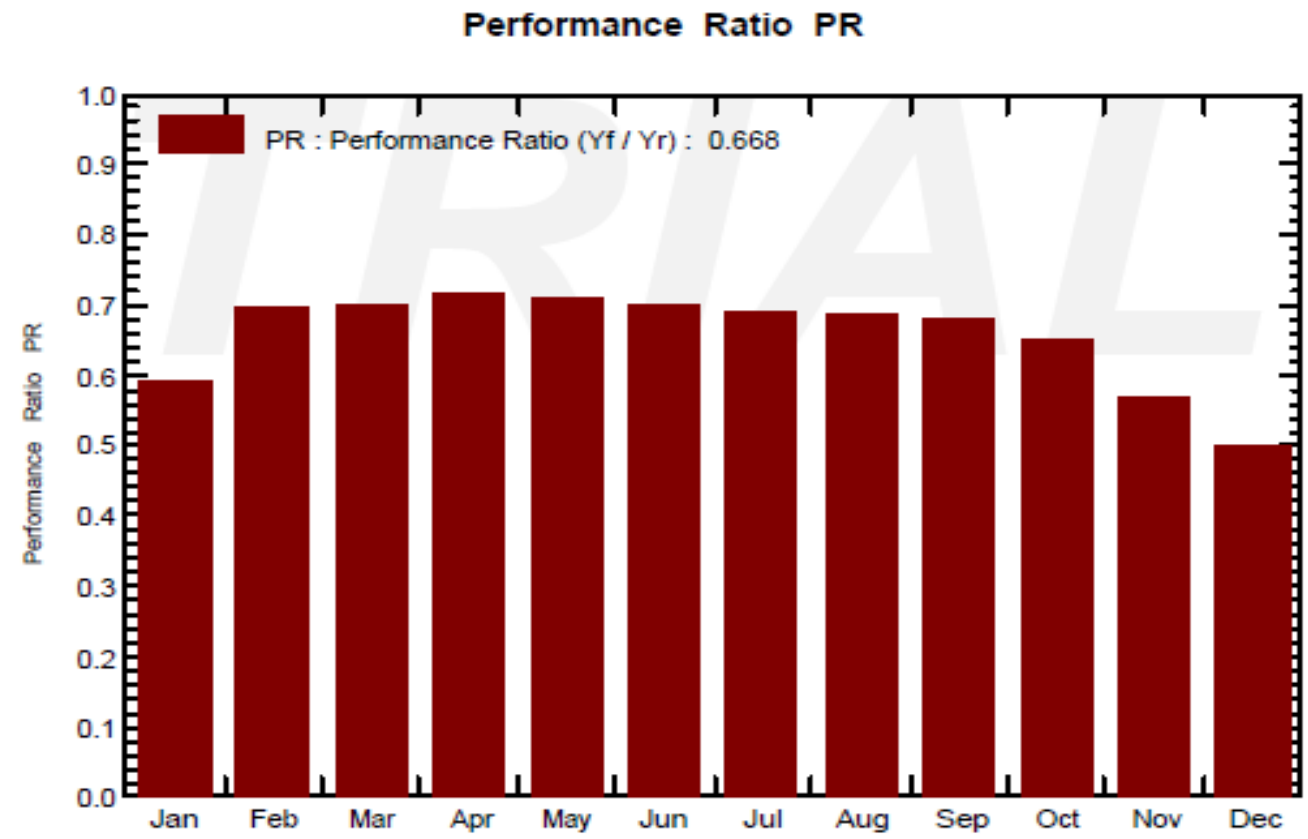

Şekil 19. performans oranı aylık değisşim grafiği

PV module: Silfab, SLG 300P

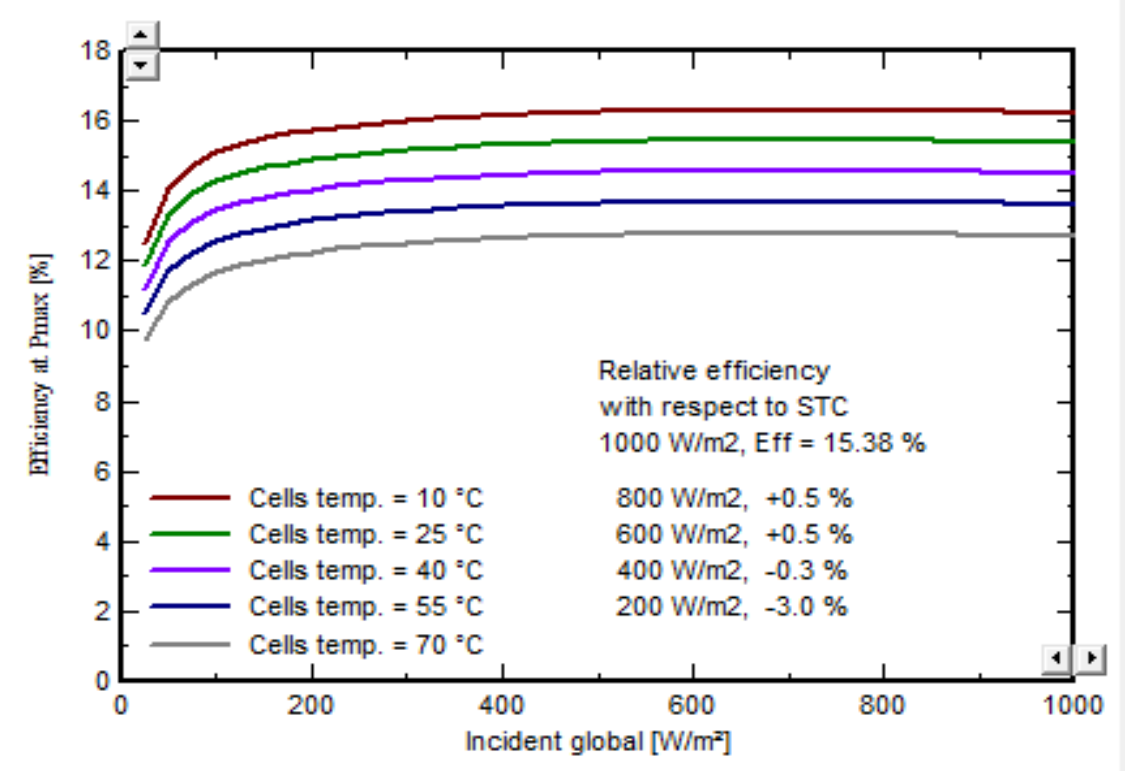

Şekil 20. PV Hücre Sicaklik/Verim Grafiği

Şekil 20’ye bakıldığında sıcaklığın yükselmesi sonucu PV hücrelerin veriminde düşme meydana geldiği görülmektedir. 


\section{Normalized productions (per installed kWp): Nominal power $30.6 \mathrm{kWp}$}

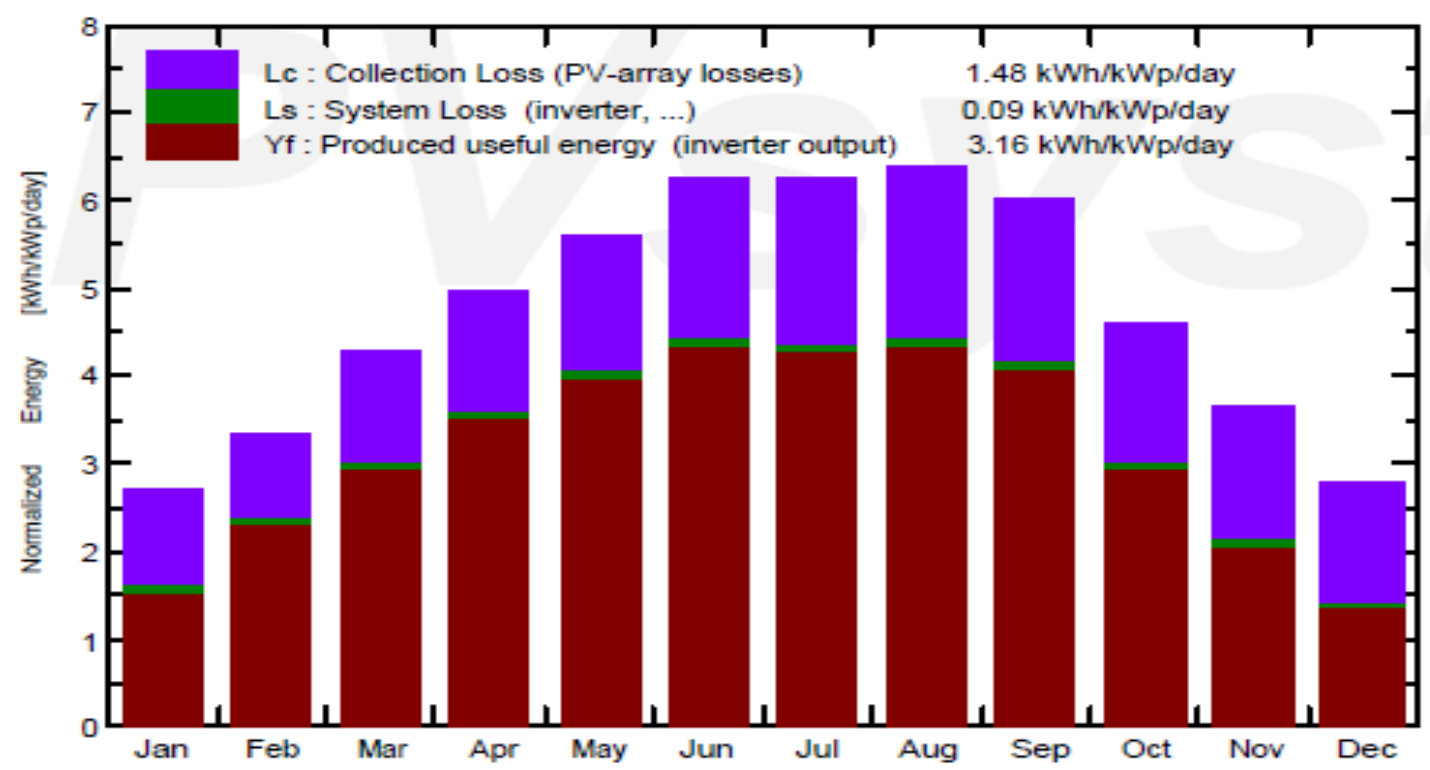

Şekil 21. Normal üretim ve kayıp faktörler

Şekil 21; yıl boyunca 4,3 (kWh / gün) toplam enerji çıkışını, 0,75 (KWh / gün) PV dizi kaybını ve 0,09 (KWh / gün) olan sistem veya inverter kayılarını temsil eder.

Balances and main results

\begin{tabular}{|l|c|c|c|c|c|c|c|c|}
\hline & $\begin{array}{c}\text { GlobHor } \\
\mathrm{kWh} / \mathrm{m}^{2}\end{array}$ & $\begin{array}{c}\text { DiffHor } \\
\mathrm{kWh} / \mathrm{m}^{2}\end{array}$ & $\begin{array}{c}\text { T_Amb } \\
{ }^{\circ} \mathrm{C}\end{array}$ & $\begin{array}{c}\text { GlobInc } \\
\mathrm{kWh} / \mathrm{m}^{2}\end{array}$ & $\begin{array}{c}\text { GlobEff } \\
\mathrm{kWh} / \mathrm{m}^{2}\end{array}$ & $\begin{array}{c}\text { EArray } \\
\mathrm{MWh}\end{array}$ & $\begin{array}{c}\text { E_Grid } \\
\text { MWh }\end{array}$ & PR \\
\hline January & 55.6 & 30.97 & 2.36 & 82.7 & 52.0 & 1.537 & 1.488 & 0.588 \\
February & 70.5 & 37.76 & 4.69 & 93.5 & 70.1 & 2.043 & 1.985 & 0.693 \\
March & 112.8 & 63.69 & 9.98 & 132.3 & 101.2 & 2.907 & 2.831 & 0.699 \\
April & 140.9 & 70.72 & 14.18 & 148.6 & 118.6 & 3.331 & 3.245 & 0.714 \\
May & 181.6 & 78.18 & 19.97 & 173.8 & 142.8 & 3.882 & 3.783 & 0.711 \\
June & 204.5 & 83.91 & 27.06 & 187.3 & 154.7 & 4.099 & 3.998 & 0.697 \\
July & 207.4 & 73.34 & 31.89 & 193.4 & 162.8 & 4.172 & 4.068 & 0.687 \\
August & 192.9 & 72.86 & 31.09 & 197.3 & 164.1 & 4.232 & 4.130 & 0.684 \\
September & 153.4 & 53.80 & 25.07 & 179.8 & 146.5 & 3.841 & 3.747 & 0.681 \\
October & 103.7 & 43.08 & 18.94 & 141.6 & 105.9 & 2.883 & 2.808 & 0.648 \\
November & 70.1 & 29.31 & 9.94 & 110.0 & 69.5 & 1.970 & 1.912 & 0.568 \\
December & 53.6 & 26.29 & 4.58 & 86.1 & 46.8 & 1.364 & 1.317 & 0.500 \\
\hline Year & 1547.1 & 663.90 & 16.72 & 1726.4 & 1334.9 & 36.261 & 35.310 & 0.668 \\
\hline
\end{tabular}

DiffHor Horizontal diffuse irradiation

T_Amb T amb.

GlobInc Global incident in coll. plane
GlobEff

EArray

E_Grid

PR
Effective Global, corr. for IAM and shadings Effective energy at the output of the array Energy injected into grid Performance Ratio

Şekil 22. Genel sonuçlar 


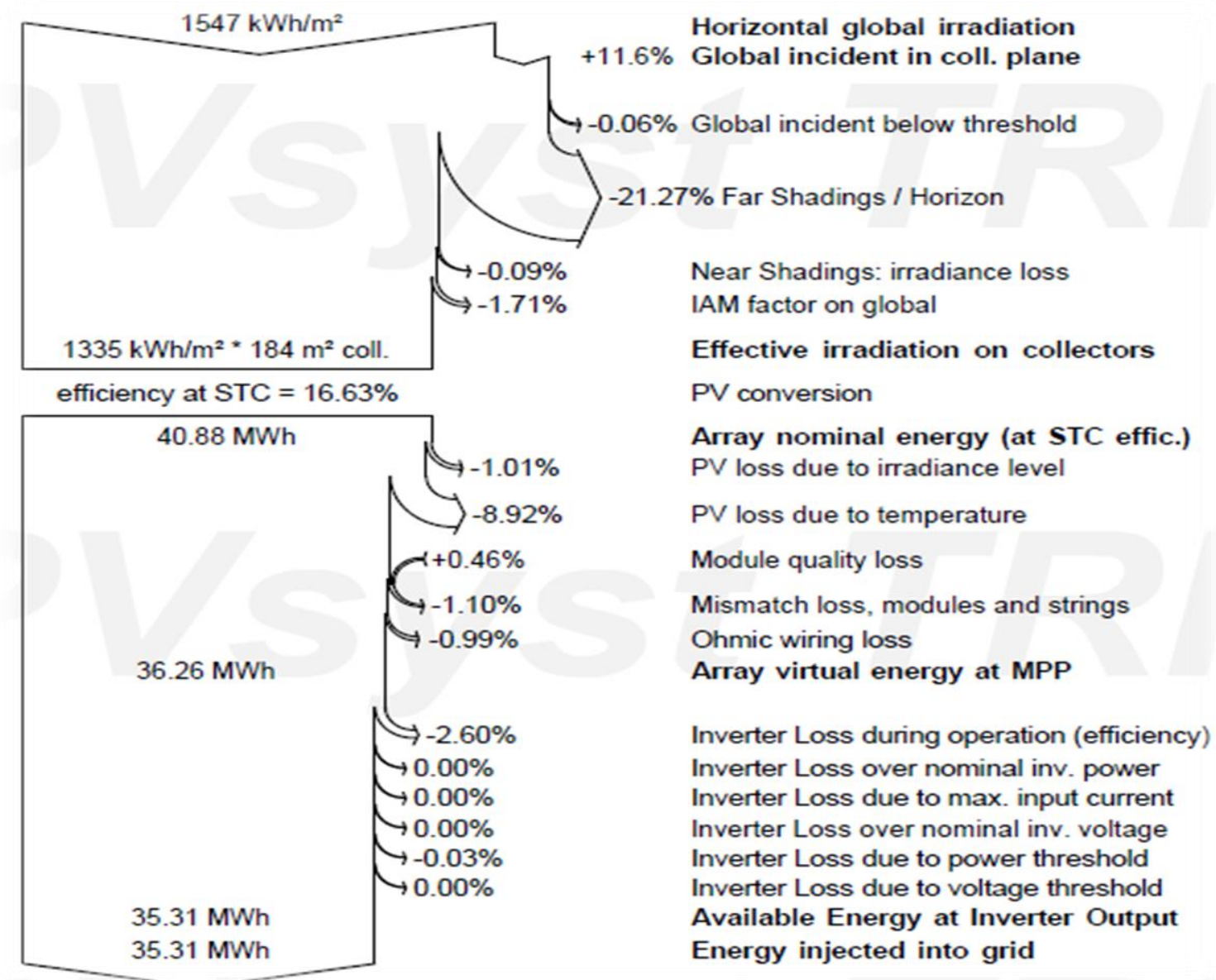

Şekil 23. Tüm yıl boyunca kayıp diyagramı

\section{Sonuç ve Değerlendirme}

Bu çalışmada, Türkiye'nin güneydoğusunda yer alan Batman şehrinin güneş enerji potansiyeli araştırılmıştır. Çalışmada, güneş enerjisinin şehir ekonomisine katkı sağlaması amacıyla; bu potansiyelin elektrik üretiminde, hidroelektrik enerjiye alternatif olarak nasıl işletilebileceği üzerine araştırma çalışmaları yapıllmıştır. Çalışmada PVsyst yazılım programı kullanılmıştır. Türkiye güneş enerjisi bakımından Dünya'nın en zengin bölgeleri arasında yer almasına karşın PV santral yatırımları oldukça az olduğu yapılan kapsamlı literatür çalışmaları sonucunda gözlenmiştir. Bu nedenle yapılan bu çalışmada PV sistemler üzerinde yoğunlaşılmış, Güneydoğu Anadolu bölgesinde yer alan Batman ilinin mevcut güneş enerjisi potansiyelini kullanmak, yaygınlaştırmak ve çatı tipi bir PV sistem tasarımının nasıl yapılacağını akademik çalışma olarak göstermek amaçlanmıştır.

$\mathrm{Bu}$ bağlamda, Batman'da bulunan bir okulun çatısına uygulanması düşünülen yerin coğrafi konumu PVsyst programında işaretlenmiş ve bölgenin meteoroloji verileri, simülasyon aracının sunduğu Meteonorm 7.2 veritabanından sentetik olarak üretilmiştir. Simülasyon aracının sağladığı meteoroloji verileri ile YEGM'den sağlanan veriler arasında çok fark olmadığı görülmüştür. Uygulanması düşünülen bu PV sistemin gerçekleştirilmesi durumunda ne gibi sonuçlarla karşılaşılacağı PVsyst simülasyon programı üzerinden değerlendirilmiştir. Ayrıca okulda üretilen 35.31 MWh-yıl enerji şebekeye satılarak okul için gelir elde edilmesi planlanmıştır. Yapılan çalışma gösteriyor ki PV sisteminden elektrik üretimi Batman ili için iyi bir seçenek olarak ön plana çıkmaktadır. Sistemin tasarlandığı yerlerin enerji ihtiyaçları göz önünde bulundurularak, sistemin bu ihtiyacın ne kadarını karşıladığı ölçülebilir ve maliyet analizleri yapılabilir. Bu çalışma referans alınarak, bu konum için daha büyük kapasiteli sistemler tasarlanabilir. $\mathrm{Bu}$ çalışmada, yenilenebilir enerjinin önemi ve coğrafi konum olarak enerji potansiyeli yüksek olan bölgelere PV sistemler kullanılarak temiz enerji elde edilmesinin önemine dikkatlerin çekilmesi amaçlanmaktadır. Çalışma için belirlenen yerin bir okul olmasının hem öğrencilere vizyon anlamında katkı sağlaması hem de dünyanın enerji konusunda göz ardı edemeyeceği güneş enerjisine eğilim konusunda çok önemli bir yere sahip olduğu düşünülmektedir. Bu çalışma için örnek bir bölge için kurulması planlanan PV güneş enerji sistemiyle elektrik enerjisi üretimi için analiz ve tasarım çalışması yapılmıştır. Bu çalışma göstermiştir ki faklı güç ve koşullara göre bu çalışma baz alınarak farklı uygulamalar için faydalı olacak bir çalışma olması amaçlanmaktadır. 


\section{Teșekkür}

$\mathrm{Bu}$ makalenin yazarları, verilen destekten dolayı Siirt Üniversitesi Otomasyon ve Kontrol Sistemleri Laboratuvar çalışanlarına teşekkür ederler.

\section{Kaynakça}

[1] Kandilli, İ., Güven, A., Karakaş, E., \& Kuncan, M. (2016, October). Güneş enerjisi kullanılarak sulama sistemleri için yeni bilgi tabanlı model, new knowledge-based model for irrigation systems with solar energy. 1. Uluslararası Akdeniz Bilim ve Mühendislik Kongresi (IMSEC 2016), 1st International Mediterranean Science and Engineering Congress (IMSEC 2016).

[2] Yadav, P., Kumar, N., \& Chandel, S. S. (2015, April). Simulation and performance analysis of a 1kWp photovoltaic system using PVsyst. In 2015 International Conference on Computation of Power, Energy, Information and Communication (ICCPEIC) (pp. 0358-0363). IEEE.

[3] Bulut, N., Kuncan, M., \& Horoz, S. (2018, August). Türkiye'de Güneş Enerjisinin Kullanım Alanları ve Siirt Güneş Enerji Potansiyeli. Ahtamara 1. Uluslararası Multidisipliner Çalışmalar Kongresi Tam Metin Kitabı. Gevaş, Van (pp. 1315-1319).

[4] Kandilli, İ., Minaz, M.R., Kuncan, M., \& Kuncan, F. (2017, October). Güneş Enerjisiyle Arabalarda Soğutma ve Isıtma Sisteminin Tasarımı. International Conference on Multidisciplinary, Science, Engineering and Technology (IMESET'17 Bitlis) (pp. 365-370)

[5] Ayım-Otu, B., Kuncan, M., Horoz, S. (2019). Research on Renewable Energy (Solar) in Ghana. Uluslararası Bilim ve Mühendislik Sетровучти, Siirt.

[6] Kandilli, İ., Karakaş, E., \& Kuncan, M.(2017). Solar Powered Boat Design. 8. International Advanced Technologies Symposium, Elazı̆̆.

[7] http://www.yegm.gov.tr/anasayfa.aspx, (ziyaret tarihi: 08.01.2020).

[8] http://gunesenerjisi.uzerine.com/index.jsp?objid=663, (ziyaret tarihi: 28.01 .2020 ).

[9] https://muhendistan.com/fotovoltaik-sistemler-nedir/, (ziyaret tarihi: 29.01.2020).

[10] https://www.enerji.gov.tr/tr-TR/Sayfalar/Gunes, (ziyaret tarihi: 08.01.2020).

[11] http://www.yegm.gov.tr/MyCalculator/,(ziyaret tarihi: 08.01.2020).

[12] http://www.yegm.gov.tr/MyCalculator/pages/72.aspx, (ziyaret Tarihi: 29.01.2020).

[13] https://batman.ktb.gov.tr/TR-56576/cografya.html, (ziyaret Tarihi: 29.01.2020).

[14]Aksangör, N.N. (2019). Ankara Şartlarında Bir Fotovoltaik Sistemin PVsyst Programı Yardımı İle Performans Analizi, Gazi Üniversitesi Fen Bilimleri Enstitüsü, Yüksek Lisans Tezi.

[15] Saraswat, R. (2016, July). Comparative performance evaluation of solar PV modules from different manufacturers in India by using PVsyst. In 2016 IEEE 1st International Conference on Power Electronics, Intelligent Control and Energy Systems (ICPEICES) (pp. 1-3). IEEE.

[16] Soualmia, A., \& Chenni, R. (2016, November). Modeling and simulation of 15MW grid-connected photovoltaic system using PVsyst software. In 2016 International Renewable and Sustainable Energy Conference (IRSEC) (pp. 702-705). IEEE.

[17] https://akhisarmyo.mcbu.edu.tr/db_images/file/gunes-enerjisi-1-1283TR.pdf, (ziyaret tarihi: 29.01.2020).

[18] Sharma, S., Kurian, C. P., \& Paragond, L. S. (2018, March). Solar PV system design using PVsyst: a case study of an academic Institute. In 2018 International Conference on Control, Power, Communication and Computing Technologies (ICCPCCT) (pp. 123-128). IEEE.

[19] Erdoğan, Y., Dinçler, T., Kuncan, M., \& Ertunç, H. M. (2014). Güneş panelleri için yüksek verimli maksimum güç noktası izleyicisi (MPPT) tasarımı. Türk Otomatik Kontrol Toplantıs1, Kocaeli-Türkiye, 1055-1060. 